\title{
THE URBAN AND THE GLOBAL IN THE EARLY MODERN PERIOD IN A COMPARATIVE PERSPECTIVE
}

(1D) Mariana Dantas ${ }^{I, 2}$

(D) Emma Hart;3

\section{ABSTRACT}

This dossier argues that the historical phenomena of the urban and the global have interacted in a dialogical fashion: urban dynamics sustained the creation of a modern and globally connected world while the global movement of people, goods, ideas, and practices helped to define urban realities and ideals. The perspective that emphasizes the interconnection between the city and globalization-the global city-is prevalent in urban studies that focus on the late twentieth and early twenty-first centuries. Applying the same analytical perspective to the early modern period using an implicit comparison between different urban centers and communities elucidates the role cities like Rio de Janeiro played in that era of globalization, as well as the impact that historical moment had on the city.

Cities - Globalization - Early Modern Period - Rio de Janeiro Atlantic World.

I Ohio University. Athens - Ohio - United States of America.

2 Mariana Dantas is the author of Black Townsmen: Urban Slavery and Freedom in the Eighteenth-Century Americas (2008). She was co-investigator of the "Global City: Past and Present" international research network project funded by the United Kingdom's Arts and Humanities Research Council between 2015 and 2017.

3 University of St. Andrews. St. Andrews - Fife - Scotland.

4 Emma Hart is the author of Building Charleston: Town and Society in the Eighteenth-Century British Atlantic World (2010) and Trading Spaces: The Colonial Marketplace and the Foundations of American Capitalism (2019). She was the principal investigator of the "Global City: Past and Present" international research network project funded by the United Kingdom's Arts and Humanities Research Council between 2015 and 2017. 


\section{O URBANO E O GLOBAL NA ERA MODERNA EM UMA PERSPECTIVA COMPARATIVA}

\section{RESUMO}

O presente dossiê parte do princípio de que o urbano e o global, enquanto fenômenos históricos, interagiram de forma dialógica na era moderna: dinâmicas urbanas sustentaram a criação de um mundo moderno globalmente conectado enquanto a movimentação global de pessoas, bens, ideias e práticas ajudou a definir realidades e imaginários urbanos. A perspectiva que salienta a interconexão entre a cidade e globalização-a cidade global-é corrente em estudos urbanos do fim do século XX e início de XXI. A adoção dessa mesma perspectiva analítica para o princípio do período moderno, a partir de uma comparação implícita entre diferentes centros e comunidades urbanas, ilumina o papel que cidades como o Rio de Janeiro tiveram naquela era de globalização, assim como a maneira pela qual aquele momento histórico definiu a cidade.

\section{PALAVIRAS-CHAVIES}

Cidades - Globalização - Era Moderna - Rio de Janeiro Mundo Atlântico. 
$\mathrm{n}$ his book, describing the six months he lived in Brazil in 1846, the American Thomas Ewbank wrote that 'the 'cries' of London are bagatelles to those of the Brazilian capital. Slaves of both sexes cry wares through every street." Whether those were fruit or vegetables, glass, ceramic, or silver wares, or yet silk and jewelry "these things, and thousand others, are hawked about daily". The comparison with London suggests that, when trying to translate his experience with Rio de Janeiro for his readers, Ewbank thought it necessary to refer to the city that, in the imagination of Americans, was most strongly associated to a vibrant urban commerce and abundance of foreign commodities. Around the same time that Ewbank published his account, Friedrich Engels wrote The Condition of the Working Class in England, where he described London as the commercial center of the world ${ }^{6}$. It is unlikely that Ewbank and his readership were familiar with Engels text at that time. They would have certainly been aware, however, of the reputation of the capital of the British Empire and the global reach of its financial and commercial institutions. By comparing the two cities, Ewbank had associated nineteenth-century Rio de Janeiro to the quintessential global city of that era.

For Ewbank, London and Rio de Janeiro were comparable in so far as both cities could deliver to their citizens any imaginable commodity at any given time. Mid-nineteenth-century Rio de Janeiro was indeed part of a complex network of commercial and financial exchanges that reached into the interior of the Brazilian territory, the different corners of the Atlantic World, and beyond ${ }^{7}$. Much as London, the Brazilian port city had acted since the seventeenth century as an important node within a network of urban centers and ports that connected different parts of the world and promoted the glo-

5 EWBANKS, Thomas. Life in Brazil, or, A journal of a visit to the land of the cocoa and the palm. New York: Harper \& brothers, 1856. p. 92-93.

6 ENGELS, Friedrich. The Condition of the Working Class in England in 1844. London: Sonnenschein \& Co, 1892. p. 23.

7 COSTA, Sérgio; GONÇALVES, Guilherme Leite. A Port in Global Capitalism: Unveiling Entangled Accumulation in Rio de Janeiro. London: Routledge, 2019. 
bal movement of goods, silver and gold, people, ideas, and practices. Despite the economic restrictions and monopolistic policies of the ancien régime, historians have demonstrated that Rio de Janeiro merchants and the port city itself had a crucial role in the economic circulation that sustained the Portuguese Empire ${ }^{8}$. But it was not only the reference to diverse goods in Ewbank's account that illustrates Rio de Janeiro's transoceanic connections. His brief mention of slaves of both sexes, charged with animating so many commercial exchanges, invokes another side of that city's transnational and global nature: the central role it had in the slave trade along the Atlantic and Indian Oceans?.

The brief passage in Ewbank's Life in Brazil highlights, without necessarily being aware of doing so, the potential globality of Rio de Janeiro, or the city's centrality to global circulations that animated and defined nineteenth-century urban realities experienced by travelers, consumers, big and small merchants, enslaved and free persons. The notable cacophony of the city, evidence of an active urban commercial sector, represents more than just trade connections: it invokes a familiar, recognizable urban environment. Such descriptions, disseminated by travelers, indicate how Rio de Janeiro contributed to reinforce notions of what was typical, expected, or desired

8 FRAGOSO, João Luís. Homens de grossa aventura: acumulação e hierarquia na praça mercantil do Rio de Janeiro, 1790-1830. Rio de Janeiro: Civilização Brasileira, 1998. PESAVENTO, Fábio. "Para além do império ultramarino português: as redes trans, extraimperiais no século XVIII." In: GUEDES, Roberto (org.). Dinâmica Imperial no Antigo Regime Português. Rio de Janeiro: Mauad Editora, 2013. p. 97-111. GUIMARÃES, Carlos Gabriel. Os ingleses no Rio de Janeiro da primeira metade do século XVIII: o caso da família Gulston, c. 1710-1720 - primeiras impressões." In: MATHIAS, Carlos Leonardo Kelmer; SAMPAIO, Antônio Carlos Jucá de; GUIMARÃES, Carlos Gabriel; RIBEIRO, Alexandre Vieira. Ramificações Ultramarinhas: Sociedade Comerciais no Âmbito do Atlântico Luso. Rio de Janeiro: Mauad Editora, 2018. p. 93-114.

9 FLORENTINO, Manolo. Em Costas Negras: uma história do tráfico atlântico de escravos entre a África e o Rio de Janeiro, séculos XVIII e XIX. Rio de Janeiro: Arquivo Nacional, 1995. BORUCKI, Alex. From Shipmates to Soldiers: Emerging Black Identities in the Río de la Plata. Albuquerque: University of New Mexico Press, 2015. p. 25-56. 
in a city ${ }^{10}$. It thus contributed to understandings of the urban in the nineteenth-century world.

The relationship between the urban and the global is the main question this dossier proposes to pursue. Rio de Janeiro's incorporation as a city in 1565 is part of a first historical process of globalization. Portugal and Spain's maritime expansion and colonizing project, which were eventually followed by those of other European communities, integrated new Atlantic routes and markets in the Americas to existing Mediterranean and Indian Ocean maritime routes and networks of economic exchange. The period between the fifteenth and nineteenth centuries witnessed, for the first time, the global circulation of goods and contact between human populations from all four corners of the globe ${ }^{11}$. The articulation of these global connections happened on ships and bodies of water, trading posts and markets, and in the various centers of power were trade and political alliances were negotiated. More specifically, it happened in towns and cities, both coastal and inland, where urban actors shaped local spaces and practices to manage better the opportunities and pressures that resulted from global forces and connectivity. The historical phenomena of the urban and the global interacted in a dialogical fashion: urban dynamics sustained the creation of a modern and globally connected world while the global movement of people, goods, ideas, and practices helped to define urban realities and ideals. The perspective that emphasizes the interconnection between the city and globalization-the global city-is prevalent in urban studies that focus on the

10 MARTINS, Luciana de Lima. O Rio de Janeiro dos viajantes: o olhar britânico (1800-1850). Rio de Janeiro: Editora Jorge Zahar, 2001.

11 ABU-LUGHOD, Janet. Before European Hegemony: The World System A.D. 1250-1350. New York: Oxford University Press, 1989. CROSBY, Alfred. The Columbian Exchange: Biological and Cultural Consequences of 1492. Westport: Greenwood, 1972. PAGDEN, Anthony. Lords of All the Worlds: Ideologies of Empire in Spain, Britain, and France, c. 1500-c.1800. New Haven: University of Connecticut Press, 1995. RUSSELL-WOOD, A.J.R. The Portuguese Empire, 1415-1808: A World on the Move. Baltimore: Johns Hopkins University Press, 1998. p. 8-26. 
late twentieth and early twenty-first centuries ${ }^{12}$. Applying the same analytical perspective to the early modern period helps us to understand better the role cities like Rio de Janeiro and urban populations played in that era of globalization, as well as the impact that historical moment had on the city.

It would not be enough, however, to interrogate the dialog between the urban and the global just on the basis of works about Rio de Janeiro. Individualized studies of cities often produce biographies of urban centers that tend to exaggerate the distinctiveness or exceptionality of a certain locality and ignore important connections with other places or contexts that are not national or imperial ${ }^{13}$. Global history, as a discipline, calls for comparisons and broad contextualization that reveal historical synchronicities, new geographies of analysis beyond the nation or empire, and connections between distinct and diachronic events ${ }^{14}$. Global urban histories also offer fertile comparisons and contextualization that support innovative narratives and analyses that are, moreover, anchored in tangible sites and human experiences ${ }^{15}$. The dossier Rio de Janeiro and the Global City combines works by internationally renowned scholars on Rio de Janeiro and on other Atlantic urban communities to develop a global urban perspective that can elucidate the process of early modern globalization and the city's centrality in that process. Together, the seven articles collected here offer two main historiographical interventions: they expand the still limited scholarship on the city of Rio de Janeiro as an important case study for discussions of global urban

12 SASSEN, Saskia. The Global City: New York, London, Tokyo. Princeton: Princeton University Press, 2013. TAYLOR, Peter; DERUDDER, Ben. World City Network: A Global Urban Analysis. London: Routledge, 2015. KING, Anthony. Writing the Global City: Globalization, Postcolonialism, and the Urban. New York: Routledge, 2016.

13 SAUNIER, Pierre-Yves; EWEN, Shane. Another Global City: Historical Explorations into the Transnational Municipal Moment. New York: Palgrave: 2008. NIGHTINGALE, Carl. Segregation: A Global History of Divided Cities. Chicago: University of Chicago Press, 2012.

14 CONRAD, Sebastian. What is Global History? Princeton: Princeton University Press, 2016.

15 ARAÚJO, Erick Assis de; SANTOS, João Júlio Gomes dos, Jr. (orgs.). História Urbana e Global: novas tendências e abordagens. Fortaleza: Editora UECE, 2018. 
history and they reinforce the relevance of a comparative perspective and a focus on the early modern period to the investigation of cities as agents of globalization.

In this dossier, readers will find an analysis of historical processes that marked the period between the seventeenth and the nineteenth century that is centered on urban communities of the Atlantic World. Luciano Figueiredo and Paul Musselwhite evaluate the historical relevance of cities-Rio de Janeiro and James Town, and cities of the British Atlantic, respectively-in the construction of imperial political geographies of global proportions. Their articles highlight the importance of urban populations to the process of articulation and negotiation of political and economic ties between the old and new worlds. In particular, they demonstrate how urban spaces helped to forge political identities and served as the stage for conflicts and confrontations that reconfigured the relationship between colony and metropole within an imperial context heavily influenced by global developments.

Jesus Bohorquez and Fabrício Prado examine trade communities and networks centered in Rio de Janeiro, Montevideo, Buenos Aires, and beyond, and their relevance to the organization of a trans-imperial economy and trans-imperial political alignments. Their articles address efforts made by the Portuguese and Spanish crowns to regulate and control increasingly globalized economies and to protect their political interests and dominance. By focusing on the commercial entanglements between difference cities, the authors demonstrate, however, that more than imperial projects, these commercial networks came into being thanks to the exertions of colonial economic agents and influence of colonial markets. Their analysis reveals further the need to consider the region's economic connections as part of a global geography much broader than the South Atlantic and as more influential in the maturation of regional political ambitions than the pro-independence ideals of the Atlantic age of revolutions.

Emma Hart, Randy Sparks, and Ynaê Lopes dos Santos focus their articles on a discussion of urban populations that are commonly marginalized in narratives of the formation of the Atlantic World 
and of globalizing processes: manual laborers, voluntary and forced migrants, Africans and their descendants, slave and freed people. The eighteenth and nineteenth centuries witnessed the intensification of commercial exchanges and movement of peoples through Atlantic routes structured around a few particular cities. Hart, Sparks, and Santos examine the trajectory of Charleston, in South Carolina, Annamaboe, on the Gold Coast, and of Rio de Janeiro. They challenge the historiography that explains the centrality of each city as the product of economic activities and the political power of elites and European or Euro-descendant populations. They show, instead, that the different initiatives and priorities of marginalized populations, African economic agents, and black slaves shaped Charleston, Annamaboe, and Rio de Janeiro, respectively. These urban actors, who have been repeatedly ignored in dominant histories of the Atlantic World, constructed spaces, markets, and urban practices that enabled economic, social, and cultural articulations that were crucial to the eighteenth and nineteenth-century world.

Through its implicit comparison between the City of Rio de Janeiro and urban centers and communities of the British and Spanish Atlantic and the African Gold Coast, this dossier offers a new perspective through which to understand the relationship between the urban and the global during the early modern period. On the one hand, it elucidates the dialogical relationship between urban dynamics and experiences and the formation of global networks of contact and exchange that marked that era. On the other, it reveals the relevance of chronologies, geographies, and historical actors still largely understudied to the process of globalization centered on cities-and therefore to the phenomenon of the global city. It aims to enrich, in this manner, a scholarship that over-privileges the so-called global north during the late twentieth and early twenty-first centuries. 


\section{Bibliography}

ABU-LUGHOD, Janet. Before European Hegemony: The World System A.D. 1250-1350. New York: Oxford University Press, 1989.

ARAUJO, Erick Assis de; SANTOS, Joao Julio Gomes dos, Jr. (orgs.). Historia Urbana e Global: novas tendencias e abordagens. Fortaleza: Editora UECE, 2018.

BORUCKI, Alex. From Shipmates to Soldiers: Emerging Black Identities in the Río de la Plata. Albuquerque: University of New Mexico Press, 2015.

CONRAD, Sebastian. What is Global History? Princeton: Princeton University Press, 2016.

COSTA, Sergio; GONCALVES, Guilherme Leite. A Port in Global Capitalism: Unveiling Entangled Accumulation in Rio de Janeiro. London: Routledge, 2019.

CROSBY, Alfred. The Columbian Exchange: Biological and Cultural Consequences of 1492. Westport: Greenwood, 1972.

ENGELS, Friedrich. The Condition of the Working Class in England in 1844. London: Sonnenschein \& Co, 1892.

EWBANKS, Thomas. Live in Brazil, or, A jornal of a visit to the land of the cocoa and the palm. New York: Harper \& brothers, 1856.

FLORENTINO, Manolo. Em costas Negras: uma historia do trafico atlantico de escravos entre a Africa e o Rio de Janeiro, seculos XVIII e XIX. Rio de Janeiro: Arquivo Nacional, 1995.

FRAGOSO, Joao Luis. Homens de grossa aventura: acumulacao e hierarquia na praca mercantil do Rio de Janeiro, 1790-1830. Rio de Janeiro: Civilizacao Brasileira, 1998.

GUIMARAES, Carlos Gabriel. Os ingleses no Rio de Janeiro da primeira metade do seculo XVIII: o caso da familia Gulston, c. 1710-1720 - primeiras impressoes." In: MATHIAS, Carlos Leonardo Kelmer; SAMPAIO, Antonio Carlos Juca de; GUIMARAES, Carlos Gabriel; RIBEIRO, Alexandre Vieira. Ramificacoes Ultramarinhas: Sociedade Comerciais no Ambito do Atlantico Luso. Rio de Janeiro: Mauad Editora, 2018. p. 93-114.

MARTINS, Luciana de Lima. O Rio de Janeiro dos viajantes: o olhar britaniCo (1800-1850). Rio de Janeiro: Editora Jorge Zahar, 2001.

NIGHTINGALE, Carl. Segregation: A Global History of Divided Cities. Chicago: University of Chicago Press, 2012. 
PAGDEN, Anthony. Lords of All the Worlds: Ideologies of Empire in Spain, Britain, and France, c. 1500-c.1800. New Haven: University of Connecticut Press, 1995.

PESAVENTO, Fábio. "Para além do império ultramarino português: as redes trans, extraimperiais no século XVIII.” In: GUEDES, Roberto (org.). Dinâmica Imperial no Antigo Regime Português. Rio de Janeiro: Mauad Editora, 2013. p. 97-111.

RUSSELL-WOOD, A.J.R. The Portuguese Empire, 1415-1808: A World on the Move. Baltimore: Johns Hopkins University Press, 1998.

SASSEN, Saskia. The Global City: New York, London, Tokyo. Princeton: Princeton University Press, 2013.

SAUNIER, Pierre-Yves; EWEN, Shane. Another Global City: Historical Explorations into the Transnational Municipal Moment. New York: Palgrave: 2008 .

TAYLOR, Peter; DERUDDER, Ben. World City Network: A Global Urban Analysis. London: Routledge, 2015. KING, Anthony. Writing the Global City: Globalization, Postcolonialism, and the Urban. New York: Routledge, 2016.

Dossier Rio de Janeiro and the Global City:

Compared stories of cities in the Modern Era of Globalization

Received in: 17/02/2020 - Approved in: 20/02/2020 